\title{
New species of Monepidosis Mamaev, 1966 and Antipodosis gen. nov., a closely related genus from New Zealand (Diptera, Cecidomyiidae)
}

\author{
Mathias JASCHHOF \\ Station Linné, Ölands Skogsby 161, SE-38693 Färjestaden, Sweden. \\ Email: mjaschhof@yahoo.de \\ urn:1sid:zoobank.org:author:8B4B11B4-7C33-41AC-A042-AA9903CDC4B1
}

\begin{abstract}
Three new species of Monepidosis Mamaev, 1966, a Holarctic genus of Porricondylinae (Diptera, Cecidomyiidae), are described: M. heterocera sp. nov. from Sweden and Germany, M. scepteroides sp. nov. from Sweden, and M. shikokuensis sp. nov. from Japan. A new porricondyline genus, Antipodosis gen. nov., is introduced for eight new species from New Zealand, named A. australis gen. et sp. nov., A. elongata gen. et sp. nov., A. granvillensis gen. et sp. nov., A. pureora gen. et sp. nov., $A$. rakiura gen. et sp. nov., $A$. rotoiti gen. et sp. nov., A. rotoroa gen. et sp. nov., and $A$. waipapa gen. et sp. nov. Male genitalic morphology indicates that Monepidosis and Antipodosis gen. nov. are closely related, together forming the Monepidosis group of genera, which stands out from the other Porricondylini. Monepidosis spatulata Spungis, 2006, a species originally described from Latvia and Lithuania, is for the first time reported to occur in Sweden.
\end{abstract}

Key words. Porricondylinae, Palearctic region, Australasian region, new genus, new species.

Jaschhof M. 2016. New species of Monepidosis Mamaev, 1966 and Antipodosis gen. nov., a closely related genus from New Zealand (Diptera, Cecidomyiidae). European Journal of Taxonomy 192: 1-24. http://dx.doi. org/10.5852/ejt.2016.192

\section{Introduction}

A recent revision of the genus Monepidosis Mamaev, 1966 recognized 14 valid species, 13 in the Palearctic and one in the Nearctic region (Jaschhof \& Jaschhof 2013; Gagné \& Jaschhof 2014). Another species of Monepidosis was described from Sweden soon after (Jaschhof \& Jaschhof 2015). Previous authors expected a considerable number of unnamed Monepidosis still to be found in the Holarctic realm (Spungis 2006; Jaschhof \& Jaschhof 2013), an expectation validated here with the description of three new species from Sweden, Germany and Japan. Monepidosis are morphologically distinct from the other Porricondylini (Cecidomyiidae, Porricondylinae) in that male genitalic structures, such as gonostyli, gonocoxites, parameres, and ejaculatory apodeme, are heavily armed in a specific manner (Jaschhof \& Jaschhof 2013). Most notably, parameres are present as two pairs of large, sclerotized tusks interlinked with each other, and the ejaculatory apodeme is developed into a long, sclerotized rod whose apex is variously modified (Jaschhof \& Jaschhof 2013: fig. 88A). Genitalic structures similar to those in Monepidosis have now been found in eight different species of undescribed Porricondylinae from New Zealand, which are obviously closely related to each other and thus classified together in a discrete new genus, Antipodosis gen. nov. Monepidosis and Antipodosis gen. nov. appear to be, if not sister groups, members of a distinct natural subset of the tribe Porricondylini, called here the Monepidosis group. 
In the present paper, the newly discovered taxa are described and named, so as to continue with the taxonomic inventory of Palearctic and especially Swedish Porricondylinae within the framework of 'The Gall Midge Project' (http://www.stationlinne.se/sv/forskning/the-gall-midge-project, accessed on 25 Nov. 2015), and to take a first step into the study of porricondyline biodiversity in Australasia. This study shows that porricondyline interrelationships are more revealing when studied globally.

\section{Material and methods}

Specimens for this study, exclusively male adults, were either picked out from general insect samples obtained by Malaise traps or were collected by sweepnet and aspirator. Most of the specimens came from various different projects initiated by the author, specifically 'The Gall Midge Project', an ongoing venture to inventory the Cecidomyiidae of Sweden (2015-2017); the 'Lestremiinae of Japan' project (1998-2000; see Jaschhof 2000); and the 'Lestremiinae of New Zealand' project (2001-2003; see Jaschhof \& Jaschhof 2003). Other specimens were provided by 'The Swedish Malaise Trap Project' (SMTP; see http://www.stationlinne.se/sv/forskning/the-swedish-malaise-trap-project-smtp, accessed on 25 Nov. 2015); were received on loan from the Senckenberg Deutsches Entomologisches Institut, Müncheberg, Germany (SDEI); or were donated by Dieter Doczkal, Zoologische Staatssammlung München, Germany.

Types and other voucher specimens of the species discussed here are available as microscopic preparations (Canada balsam inclusions) and shall be finally deposited in the following collections: Entomological Collection of Kyushu University, Fukuoka, Japan (KUEC); Naturhistoriska Riksmuseet Stockholm, Sweden (NHRS); New Zealand Arthropod Collection, Tamaki, Auckland, New Zealand (NZAC); and SDEI.

The procedures of specimen preparation and identification as well as the morphological terminology used in adult Porricondylinae were recently described by Jaschhof \& Jaschhof (2013). Several morphological terms, some of which specific to the porricondylines treated here, are explained in Figs 2, 10 and 12 of the present paper, with the following abbreviations used:

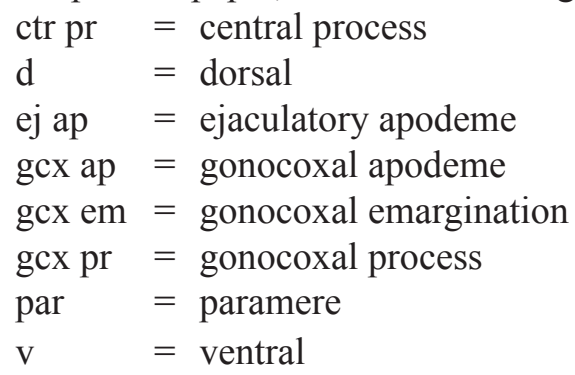

Since the male gonocoxites of almost all Porricondylinae, including Monepidosis and Antipodosis gen. nov., are largely merged into a single structure, they are described as a unit. Body length was measured from the head to the genitalia. Arrows $(\downarrow)$ are used to highlight important diagnostic characters in both the taxonomic descriptions and illustrations. The descriptive sections, titled here 'Other characters', mention only those characters that are not referred to in the diagnoses and differential diagnoses, respectively. Taxa are treated in alphabetical order. 


\title{
Results
}

\author{
Class Insecta Linnaeus, 1758 \\ Order Diptera Linnaeus, 1804 \\ Suborder Bibionomorpha Hennig, 1954 \\ Family Cecidomyiidae Newman, 1834 \\ Subfamily Porricondylinae Kieffer, 1913 \\ Genus Antipodosis gen. nov. \\ urn:Isid:zoobank.org:act:B8BF652D-AFFF-418C-829E-608741C68503
}

\section{Type species}

Antipodosis australis gen. et sp. nov., described below.

\section{Diagnosis}

Larvae and females of Antipodosis gen. nov. are unknown, so this genus is based solely on characters of males. Antipodosis gen. nov. are small, inconspicuous Porricondylini, exhibiting the characters typical of that tribe and coming under the group of genera with 14 flagellomeres and without basitarsal spines ("group Aa" in Jaschhof \& Jaschhof 2013). Antipodosis gen. nov. stands out from most other Porricondylini in that vein $\mathrm{CuA}_{1}$ runs parallel to $\mathrm{CuA}_{2}$ rather than approaching or joining it (Fig. 1A versus $1 \mathrm{~B})$, and the eye bridge is longer dorsally (5-10 versus $2-3$ ommatidia). The structure of the genitalia is genus-specific. Most notably, the two gonocoxal apodemes, which in other Porricondylini are long bars separated from one another (Fig. 12), tend to merge into a single plate (Fig. 2); parameres are typically present as two pairs (a ventral and a dorsal pair) of strongly sclerotized tusks interlinked with each other (Fig. 2); and the ejaculatory apodeme, whose length exceeds that of the gonocoxites, is typically a strongly sclerotized rod with apical modifications.
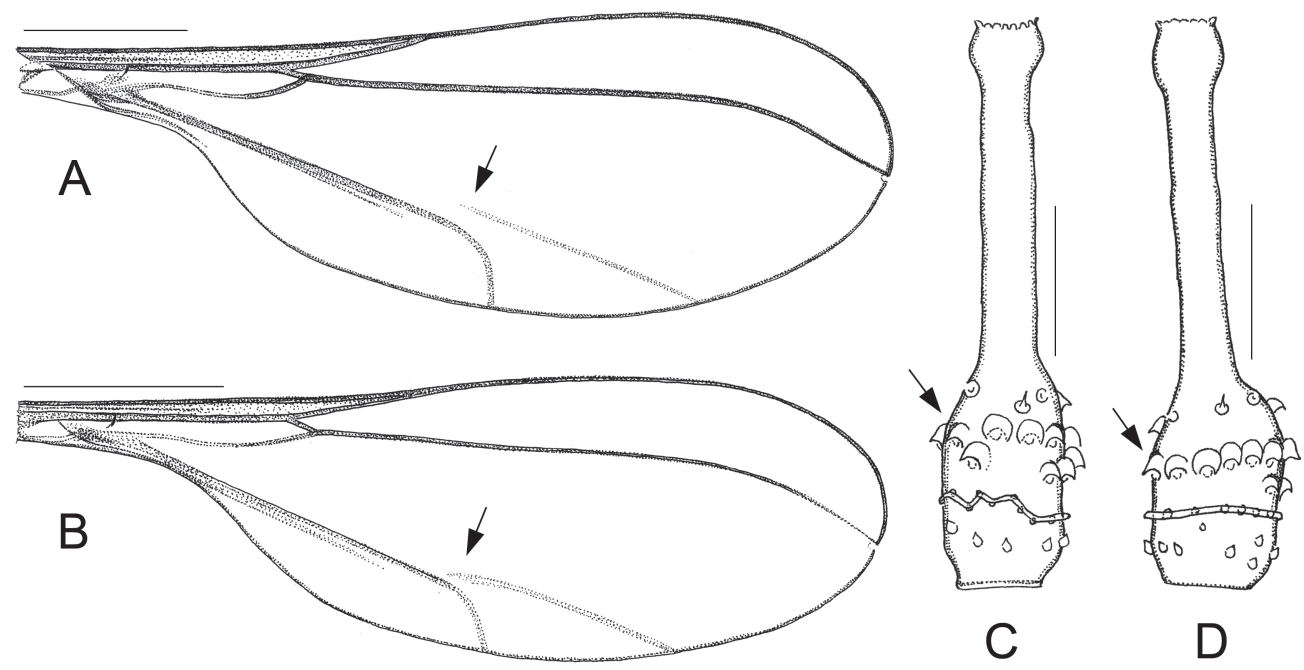

Fig. 1. Male morphology of Antipodosis gen. nov. and Monepidosis Mamaev, 1966. A. Wing of A. granvillensis gen. et sp. nov., holotype, setae omitted. B. Wing of M. shikokuensis sp. nov., holotype, setae omitted. C. Fourth flagellomere of A. rakiura gen. et sp. nov., holotype, lateral. D. Fourth flagellomere of $M$. scepteroides sp. nov., holotype, lateral. Scale lines: $\mathrm{A}-\mathrm{B}=0.50 \mathrm{~mm}, \mathrm{C}-\mathrm{D}=0.05 \mathrm{~mm}$. 


\section{Differential diagnosis}

The genus Antipodosis gen. nov. is similar to Monepidosis (Jaschhof \& Jaschhof 2013), differing from it as follows: the eye bridge is longer; sensory hairs (= setae with hooded sockets) on the flagellomeres are dispersed rather than aligned to form a single whorl (Fig. 1C versus 1D); wings are wider (with length/width ratios usually < 3.0); $\mathrm{CuA}_{1}$ does not approach but runs parallel to $\mathrm{CuA}_{2}$ (Fig. 1 A versus 1B); the gonostylar apex bears typically a pectinate tooth (Figs 2A, 7A), but never a large plate-like spine (Figs 10A-B, 11B); gonocoxites have a distinct ventral emargination (Fig. 2A) and have no central processes (Fig. 10A); and the anterior portions of the gonocoxal apodemes are either short and separated (Fig. 6A), or merged into a single, long plate (Fig. 2A).

\section{Etymology}

The name Antipodosis is composed of Antipod-, from the Latin antipodes, for 'antipodes', and the ending -osis, from Monepidosis, a closely related genus. Gender is feminine.

\section{Other characters}

BODY LENGTH. 1.7-2.3 mm.

HeAD. Postfrons asetose. Antenna longer than body. Scape and pedicel usually yellowish, lighter than flagellum. Circumfila on flagellomeres 1 to $11-14$, evenly ring-shaped or slightly sinuous, in $A$. rotoiti gen. et sp. nov. with short posterior extensions. Neck of fourth flagellomere longer than node; node apart from circumfilum with microtrichia, short setae forming a basal whorl, numerous long sensory hairs (Fig. 1C). Palpus as long as head height or longer, 4 subcylindrical segments.

THORAX. Scutum with a few lateral and dorsocentral setae. Both anepisternum and anepimeron setose.

WING (Fig. 1A). Longer than body. Length/width 2.5-2.9 (in A. australis gen. et sp. nov. exceptionally 3.1). Costal cell narrow, reinforced. Rs strongly oblique, in line with $\mathrm{R}_{5}$. M usually absent, in A. waipapa gen. et sp. nov. a remnant $\mathrm{M}$ present at wing margin.

Legs. Densely covered with narrow scales. Claws crescent-shaped, with 1 large and 2-3 smaller teeth basally. Empodia rudimentary, as far as known.

ABdomen. Tergites 2-5(-6) varyingly strongly desclerotized at center, setae aligned in rows along margins; other tergites evenly sclerotized, setae aligned in 1 transverse row. Sternite 1 unsclerotized, asetose, other sternites evenly sclerotized, setae dispersed. Pleural membrane very sparsely setose.

Genitalia (Figs 2-9). Ninth tergite either subtrapezoid or rounded posteriorly. Gonostylus either elongate, tapered towards apex, or flattened, with broadly rounded apex; typically a pectinate tooth apically, 1-2 bristles medially; basolateral apodeme large. Gonocoxites: ventral emargination approximately U-shaped, with glabrous, sclerotized rim; medial bridges sometimes with membranous outgrowths that occupy parts of the ventral emargination (Figs 7A, 8A, 9A). Ventral parameres usually bent laterally or dorsolaterally, occasionally interconnected mediobasally (Figs 3B, 9B); dorsal parameres usually bent dorsally (thus often hardly visible in ventral view); parameral apodemes usually large. Base of ejaculatory apodeme either widened (visible in ventral view, Fig. 5B) or flattened (visible in lateral view). Accessory gland ducts, or their merging points with ejaculatory apodeme, distinct. Both hypoproct and cerci present as two setose, medially merged lobes (omitted in illustrations); cerci longer than hypoproct.

\section{Distribution and phenology}

The genus Antipodosis gen. nov. is to present knowledge endemic to New Zealand. Of eight species identified, two occur on the North Island and six on the South Island including Stewart Island. Almost 
all the specimens known of Antipodosis gen. nov. were collected in native forest in austral summer (Nov.-Jan.).

\section{Phylogenetic remarks}

The peculiarity of Antipodosis gen. nov. that gonocoxal apodemes tend to merge into a large plate is a derived character state not known in other Porricondylini, thus an autapomorphy. From what is currently known of world Porricondylini, it appears that Antipodosis gen. nov. is most closely related to Monepidosis. Compelling evidence of this relationship is provided by the parameres and the ejaculatory apodeme, whose basic structure is identical in the two genera. Both are therefore combined in what is here called the Monepidosis group. The relationships of this group to other Porricondylini remain obscure for the time being. With respect to male morphology, Antipodosis gen. nov. has retained more ancestral traits than Monepidosis. For example, in Antipodosis gen. nov. the two gonocoxites are largely separated by the ventral emargination, whereas in Monepidosis they are lengthwise connected, with the connecting bridge even further modified to bear a pair of processes. Furthermore, in Antipodosis gen. nov. the gonostylar apex is equipped with a pectinate tooth of fine, separate spines, which is the structure found in many other Porricondylinae and Porricondylini, whereas in Monepidosis the spines are merged into a large, plate-like tooth that encircles much of the gonostylus' distal half. Concurrent in Antipodosis gen. nov. and Monepidosis, the basic patterns of parameres and ejaculatory apodeme undergo various modifications, which may be so pronounced that the generic affiliations of the respective species are obscured (see Antipodosis elongata gen. et sp. nov., Fig. 3; Monepidosis shikokuensis sp. nov., Fig. 12). One may argue that such extreme variations are likely to evolve over long periods of time and both Antipodosis gen. nov. and Monepidosis might be phylogenetically old lineages.

Antipodosis australis gen. et sp. nov. urn:1sid:zoobank.org:act:45076E74-E261-4A53-804F-8264851F5133

Fig. 2A-B

\section{Diagnosis}

A combination of genitalic characters is specific to A. australis sp. nov., as follows (Fig. 2A-B). Of the gonocoxites (Fig. 2A), the processes are small but prominent $(\downarrow)$ ); the ventral emargination, whose shape is reminiscent of an inverted bell, has a broad glabrous rim that almost reaches the anterior gonocoxal margin $(\downarrow)$, and the apodemes are merged into a large subrectangular plate $(\downarrow)$. The ejaculatory apodeme has a distinct subapical extension ( $\downarrow$, Fig. 2B).

\section{Differential diagnosis}

Antipodosis australis gen. et sp. nov. resembles A. pureora gen. et sp. nov. in having elongate, slender gonostyli; a long, plate-like gonocoxal apodeme; two pairs of unmodified parameral tusks, and a singlepointed, straight ejaculatory apodeme. Characters to differentiate between the two species are provided by the gonocoxal emargination, which in A. australis gen. et sp. nov. is bell-shaped (Fig. 2A) and in A. pureora gen. et sp. nov. U-shaped (Fig. 5A), and by the ejaculatory apodeme, whose base is flattened in A. australis gen. et sp. nov. (not visible in the ventral view depicted in Fig. 2B) and widened in A. pureora gen. et sp. nov. (Fig. 5B).

\section{Etymology}

The name australis is a Latin adjective meaning 'southern', which refers to the distribution of this species in the two southern main islands of New Zealand. 


\section{Type material}

\section{Holotype}

NEW ZEALAND: $\widehat{0}$, South Island, Buller, Lake Rotoroa, mixed podocarp / southern beech forest, 450 m, 15 Jan. 2001, Malaise trap “15”, Department of Conservation St. Arnaud (NZAC).

\section{Paratype}

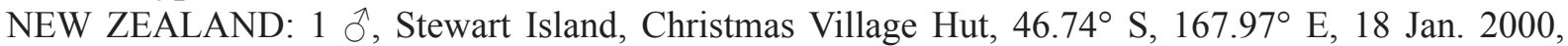
Malaise trap, R.K. Didham (NZAC).

\section{Other characters}

BODY LENGTH. $2.0 \mathrm{~mm}$.

HEAD. Eye bridge 5-6 ommatidia long dorsally. Circumfila on flagellomeres 1 to $13-14$. Neck of fourth flagellomere 1.8-1.9 times longer than node. Palpus as long as height of head.

WING. Length/width 3.0-3.1.

LEGS. Empodia rudimentary.

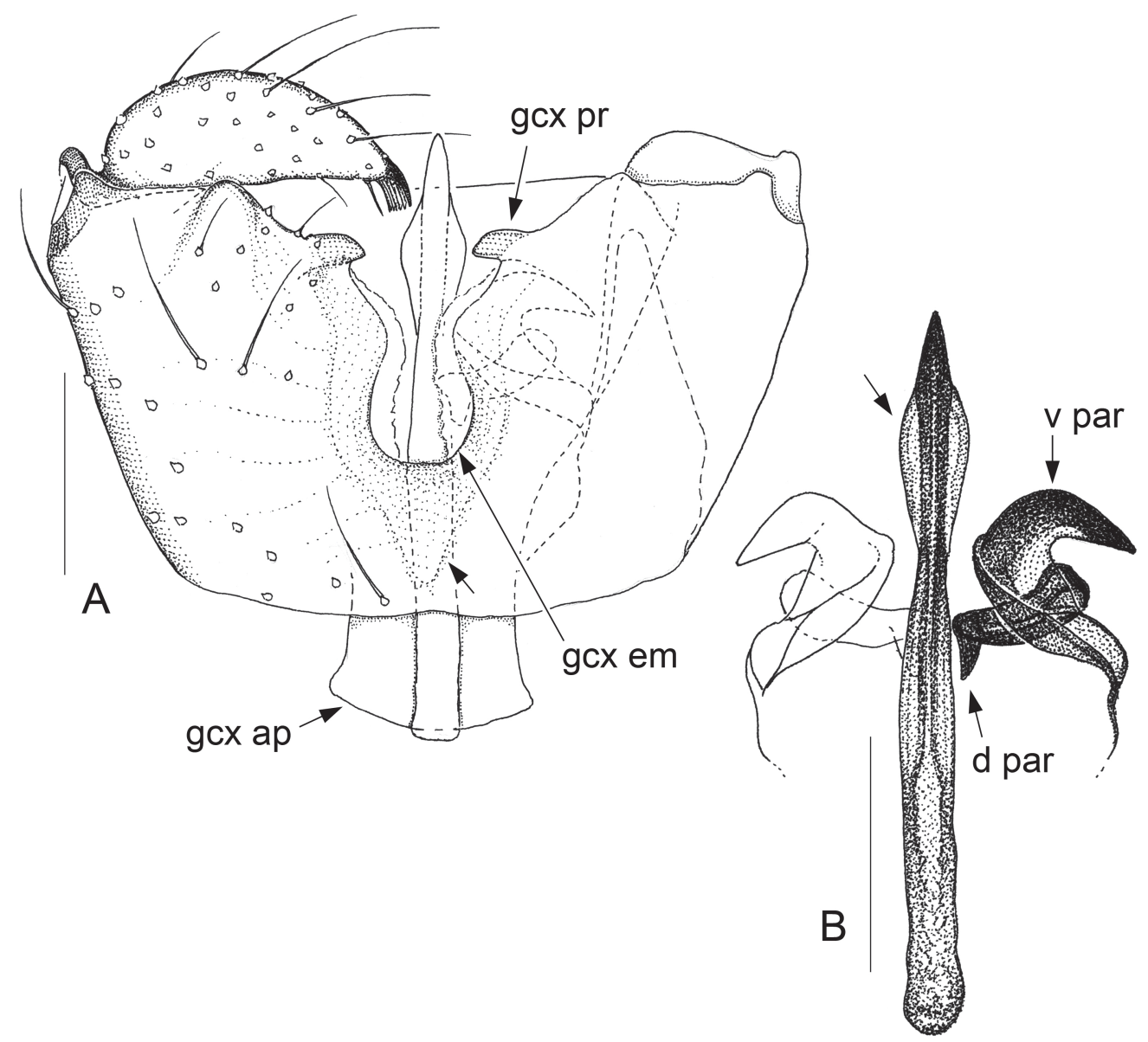

Fig. 2. Antipodosis australis gen. et sp. nov., $\widehat{0}$, holotype. A. Genitalia, ventral. B. Parameres and ejaculatory apodeme, ventral. Scale lines: $0.05 \mathrm{~mm}$. 
Terminalia (Fig. 2A-B). Ninth tergite subtrapezoid, medially unsclerotized, asetose. Gonostylus strongly tapered towards apex, pectinate tooth narrow (Fig. 2A). Gonocoxites with small protuberances on ventroposterior margin; apodemes protrude clearly beyond ventroanterior margin (Fig. 2A). Ventral parameral tusks bent dorsolaterally, dorsal tusks bent dorsally (Fig. 2B).

Antipodosis elongata gen. et sp. nov.

\section{urn:Isid:zoobank.org:act:CD29F5F3-E563-4898-B8ED-E3D69204939B}

Fig. 3A-B

\section{Diagnosis}

Genitalic structures, such as gonocoxites, parameres and ejaculatory apodeme, are conspicuously elongated (Fig. 3A-B), making A. elongata gen. et sp. nov. the most deviant species of Antipodosis gen. nov. Adding to its exceptionality, ventral and dorsal parameres are largely merged with each other,

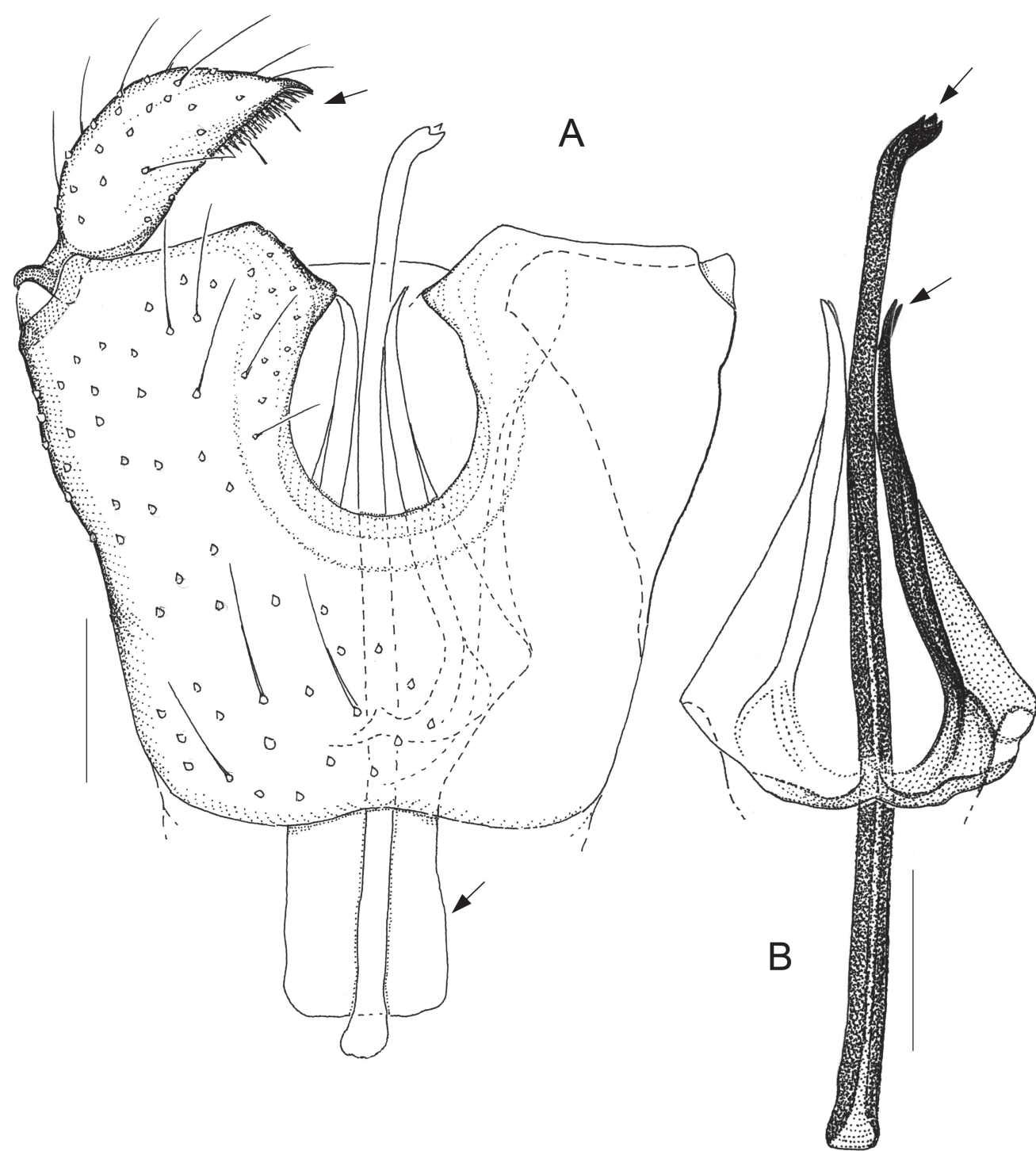

Fig. 3. Antipodosis elongata gen. et sp. nov., $\widehat{0}$, holotype. A. Genitalia, ventral. B. Parameres and ejaculatory apodeme, ventral. Scale lines: $0.05 \mathrm{~mm}$. 
leaving only the extreme apices separated ( $\downarrow$, Fig. 3B). The ejaculatory apodeme is three-pointed apically ( $\downarrow$, Fig. 3B). The gonostylus, which is strongly flattened, has a fringe of short, thick microtrichia at the broadly rounded apex ( $\downarrow$, Fig. 3A).

\section{Etymology}

The name elongata, a Latin adjective meaning 'elongate', refers to the genitalia of this species.

\section{Type material}

\section{Holotype}

NEW ZEALAND: J, South Island, Buller, Lake Rotoiti, southern beech forest, 640 m, 31 Jan. 2001, Malaise trap “2”, Department of Conservation St. Arnaud (NZAC).

\section{Other characters}

\section{BODY LENGTH. $2.2 \mathrm{~mm}$.}

HEAD. Eye bridge 7-8 ommatidia long dorsally. Circumfila on flagellomeres 1-14. Neck of fourth flagellomere 1.5 times longer than node. Palpus 1.6 times longer than height of head.

WING. Length/width 2.9 .

LEGS. Acropods missing, so length of empodia unknown.

Terminalia (Fig. 3A-B). Ninth tergite broadly rounded posteriorly. Gonocoxites (Fig. 3A): processes small, subtriangular; ventral emargination large, $\mathrm{U}$-shaped, with glabrous rim basally; posterior portions extensively unsclerotized; apodemes merged anteriorly to form subrectangular plate that protrudes clearly beyond ventroanterior gonocoxal margin $(\downarrow)$. Apex of ejaculatory apodeme bent ventrally (Fig. 3B). Parameres directed posteriorly, only apices bent slightly dorsally; apodemes small (Fig. 3B).

Antipodosis granvillensis gen. et sp. nov. urn:1sid:zoobank.org:act:6CF5586C-2552-4D08-AD8F-F6F208ADE6D7

Figs $1 \mathrm{~A}, 4 \mathrm{~A}-\mathrm{C}$

\section{Diagnosis}

Antipodosis granvillensis gen. et sp. nov. is distinguished from the congeneric species by two unique characters: the gonostylus bears apically a single, tooth-like spine ( $\downarrow$, Fig. 4A), and the dorsal parameral tusks are two-branched ( $\downarrow$, Fig. 4B).

\section{Etymology}

The name granvillensis, an adjective, is derived from Granville State Forest in the West Coast region of South Island, which is the type locality of this species.

\section{Type material}

\section{Holotype}

NEW ZEALAND: $\widehat{\jmath}$, South Island, West Coast, Ahaura, Granville State Forest, hard beech forest, 170250 m, Dec. 1994, Malaise trap “2 GUL 7K”, J. Hutcheson (NZAC).

\section{Paratype}

NEW ZEALAND: 1 ภ, South Island, Buller, Lake Rotoroa, mixed podocarp/southern beech forest, 450 m, 15 Jan. 2001, Malaise trap “15”, Department of Conservation St Arnaud (NZAC). 


\section{Other characters}

BODY LENGTH. $2.2 \mathrm{~mm}$.

HEAD. Eye bridge 6-7 ommatidia long dorsally. Circumfila on flagellomeres 1-11. Neck of fourth flagellomere 1.4 times longer than node. Palpus 1.3 times longer than height of head.

WING (Fig. 1A). Length/width 2.7.

LEGS. Empodia rudimentary.

Terminalia (Fig. 4A-C). Ninth tergite subtrapezoid. Gonostylus elongate, slightly curved, strongly tapered towards apex (Fig. 4A). Gonocoxites (Fig. 4A) broadly rounded ventroanteriorly; processes inconspicuous, subrectangular $(\downarrow)$; ventral emargination evenly U-shaped, with broad glabrous rim basally; apodemes short, reaching just to ventral gonocoxal margin, slightly bilobed anteriorly.

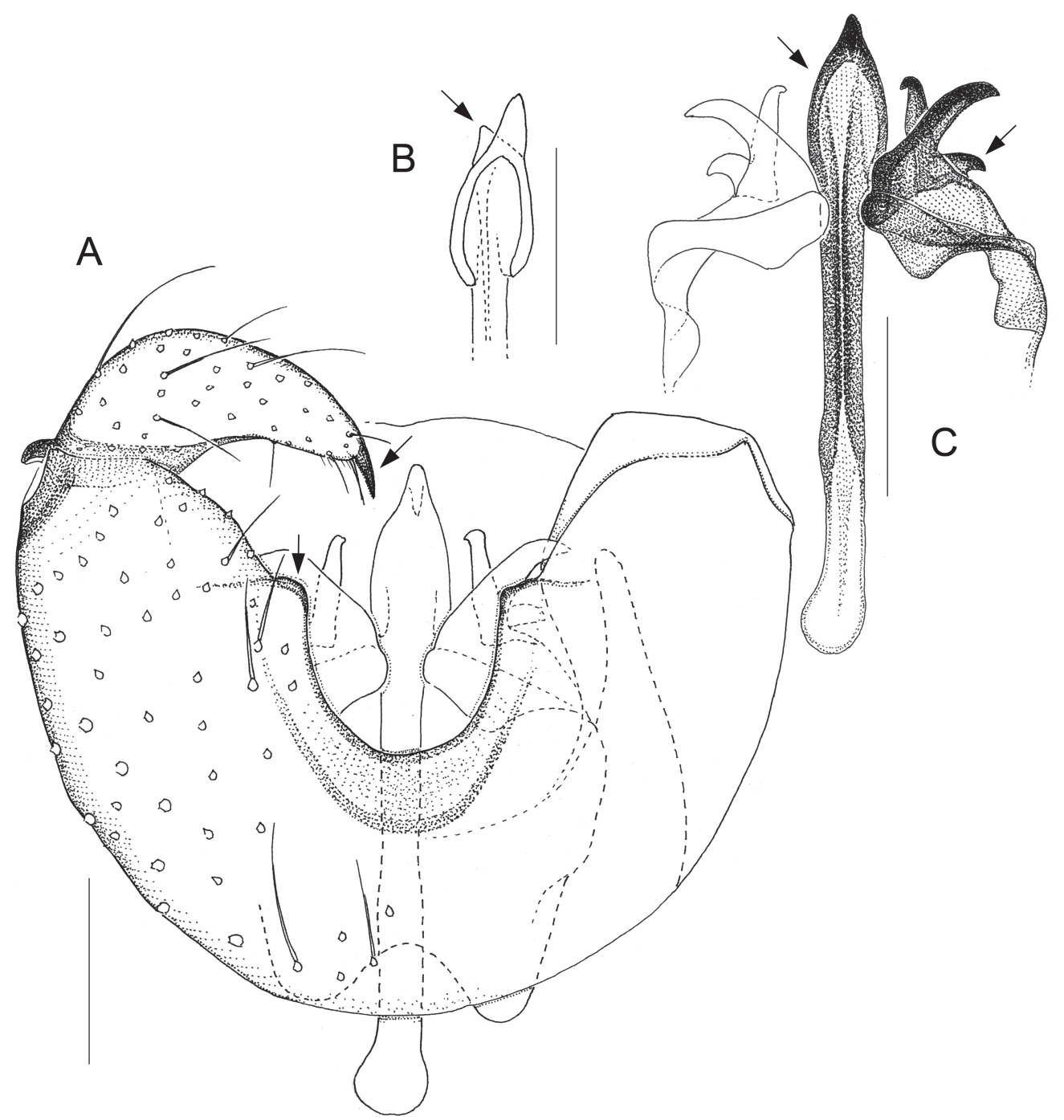

Fig. 4. Antipodosis granvillensis gen. et sp. nov., Ô. A. Genitalia, ventral, holotype. B. Apex of ejaculatory apodeme, ventral, paratype. C. Parameres and ejaculatory apodeme, ventral, holotype. Scale lines: $0.05 \mathrm{~mm}$. 
Ejaculatory apodeme with ovoid apical extension, two-pointed, the ventral point slightly bent ventrally ( $\downarrow$, Fig. 4B-C), basal portion poorly sclerotized. Ventral parameral tusks bent dorsolaterally, dorsal tusks bent dorsoposteriorly; apodemes large (Fig. 4B).

\section{Antipodosis pureora gen. et sp. nov. urn:lsid:zoobank.org:act:B96B677C-C249-43BE-8B84-B7AF37B62C3D}

Fig. 5A-B

\section{Diagnosis}

A combination of genitalic characters is specific to A. pureora gen. et sp. nov., as follows (Fig. 5A-B). Of the gonocoxites (Fig. 5A), the processes are small and subtriangular ( $\downarrow$ ), the large ventral emargination is perfectly $U$-shaped $(\downarrow)$, and the apodemes are merged into a large plate with rounded margins $(\downarrow)$. The base of the ejaculatory apodeme is strongly widened ( $\downarrow$, Fig. 5B), which is unique in Antipodosis gen. nov.

\section{Differential diagnosis}

Antipodosis pureora gen. et sp. nov. is similar to both A. australis gen. et sp. nov. and A. rotoroa gen. et sp. nov. The three species differ from each other in the ejaculatory apodeme, which is strongly widened basally in A. pureora gen. et sp. nov. (Fig. 5B), markedly widened subapically in A. australis gen. et sp. nov. (Fig. 2B), and two-pointed apically in A. rotoroa gen. et sp. nov. (Fig. 8B). Other interspecific distinctions are described under each of the species.

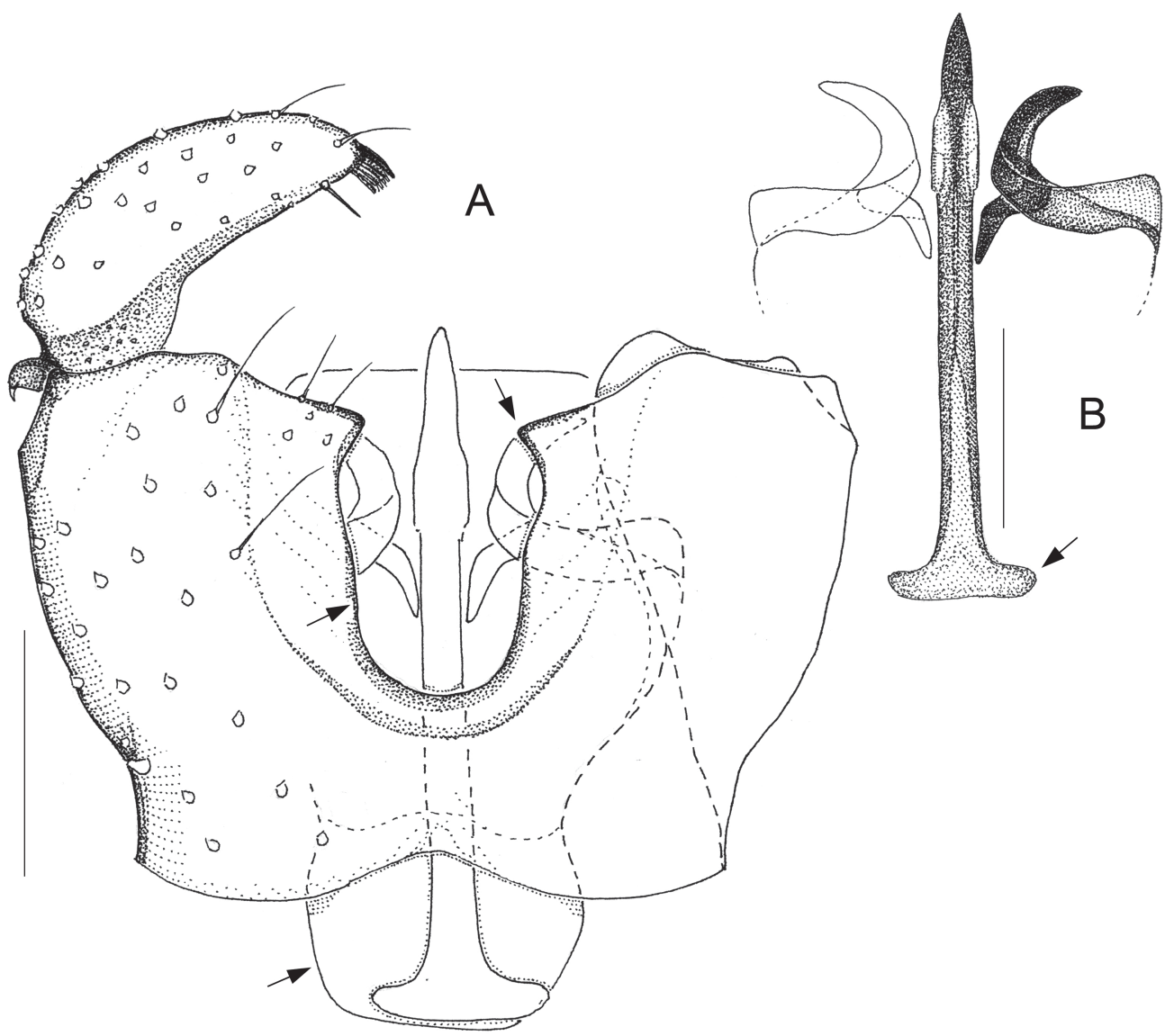

Fig. 5. Antipodosis pureora gen. et sp. nov., ${ }^{\lambda}$, holotype. A. Genitalia, ventral. B. Parameres and ejaculatory apodeme, ventral. Scale lines: $0.05 \mathrm{~mm}$. 
JASCHHOF M., Taxonomy of Monepidosis and Antipodosis gen. nov.

\section{Etymology}

The name pureora is from the Maori language, referring to Pureora Forest, one of the largest intact tracts of native podocarp forest in the North Island and collection site of this species.

\section{Type material}

\section{Holotype}

NEW ZEALAND: ${ }^{\Uparrow}$, North Island, Taupo, Pureora Forest, Waipapa Reserve, podocarp forest, $570 \mathrm{~m}$, 8 Dec. 1983, Malaise trap, J. Hutcheson (NZAC).

\section{Other characters}

BODY LENGTH. About $1.7 \mathrm{~mm}$.

HEAD. Eye bridge 4-5 ommatidia long dorsally. Apices of antennae missing. Neck of fourth flagellomere 1.7 times longer than node. Palpus longer than height of head.

WING. Length/width 2.7 .

LEGS. Acropods missing, so length of empodia unknown.

Terminalia (Fig. 5A-B). Ninth tergite subtrapezoid, medially unsclerotized, asetose. Gonostylus elongate, strongly tapered towards apex, pectinate tooth narrow (Fig. 5A). Gonocoxal emargination with glabrous rim basally; apodemes protrude beyond ventroanterior margin (Fig. 5A). Ejaculatory apodeme pointed apically, straight, slightly widened at merging points with accessory gland ducts (Fig. 5B). Ventral parameral tusks curved dorsolaterally, dorsal tusks directed dorsally (Fig. 5B).

Antipodosis rakiura gen. et sp. nov. urn:Isid:zoobank.org:act:7D191604-3021-4E5E-9E8D-DDD34DC58310

Figs $1 \mathrm{C}, 6 \mathrm{~A}-\mathrm{B}$

\section{Diagnosis}

A character readily distinguishing A. rakiura gen. et sp. nov. from all other Antipodosis gen. nov. is that the dorsal portions of the parameres are merged into a rhomboid shaped plate ( $\downarrow$, Fig. 6B), with the result that only one pair of tusks remains ventrally. Other genitalic structures distinctive of this species are the gonostylus, which is swollen on the basal two thirds and flattened on the apical third ( $\downarrow$, Fig. 6A), and the gonocoxites, which have prominent, rectangular processes $(\downarrow)$.

\section{Etymology}

The species epithet rakiura is identical with the Maori name commonly used for Stewart Island where this species was found.

\section{Type material}

Holotype

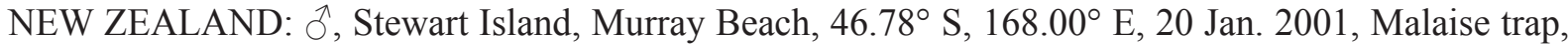
R.K. Didham (NZAC).

\section{Other characters}

BODY LENGTH. $2.0 \mathrm{~mm}$. 
HEAD. Eye bridge 4-5 ommatidia long dorsally. Circumfila present on flagellomeres 1-12. Neck of fourth flagellomere 1.6 times longer than node. Palpus 1.2 times longer than height of head.

WING. Length/width 2.8 .

Legs. Empodia rudimentary.

TERMinaLia (Fig. 6A-B). Ninth tergite broadly rounded posteriorly, only medially sclerotized. Gonostylar apex broadly rounded, pectinate tooth wide (Fig. 6A). Gonocoxites (Fig. 6A): ventral emargination small, perfectly U-shaped, with glabrous rim basally; dorsal portions with subtriangular projections on posterior margin; apodemes short, bilobed anteriorly. Ejaculatory apodeme (Fig. 6B): apex pointed, straight; base flattened; accessory gland ducts unusually distinct. Parameral tusks curved dorsolaterally; parameral apodemes small (Fig. 6B).

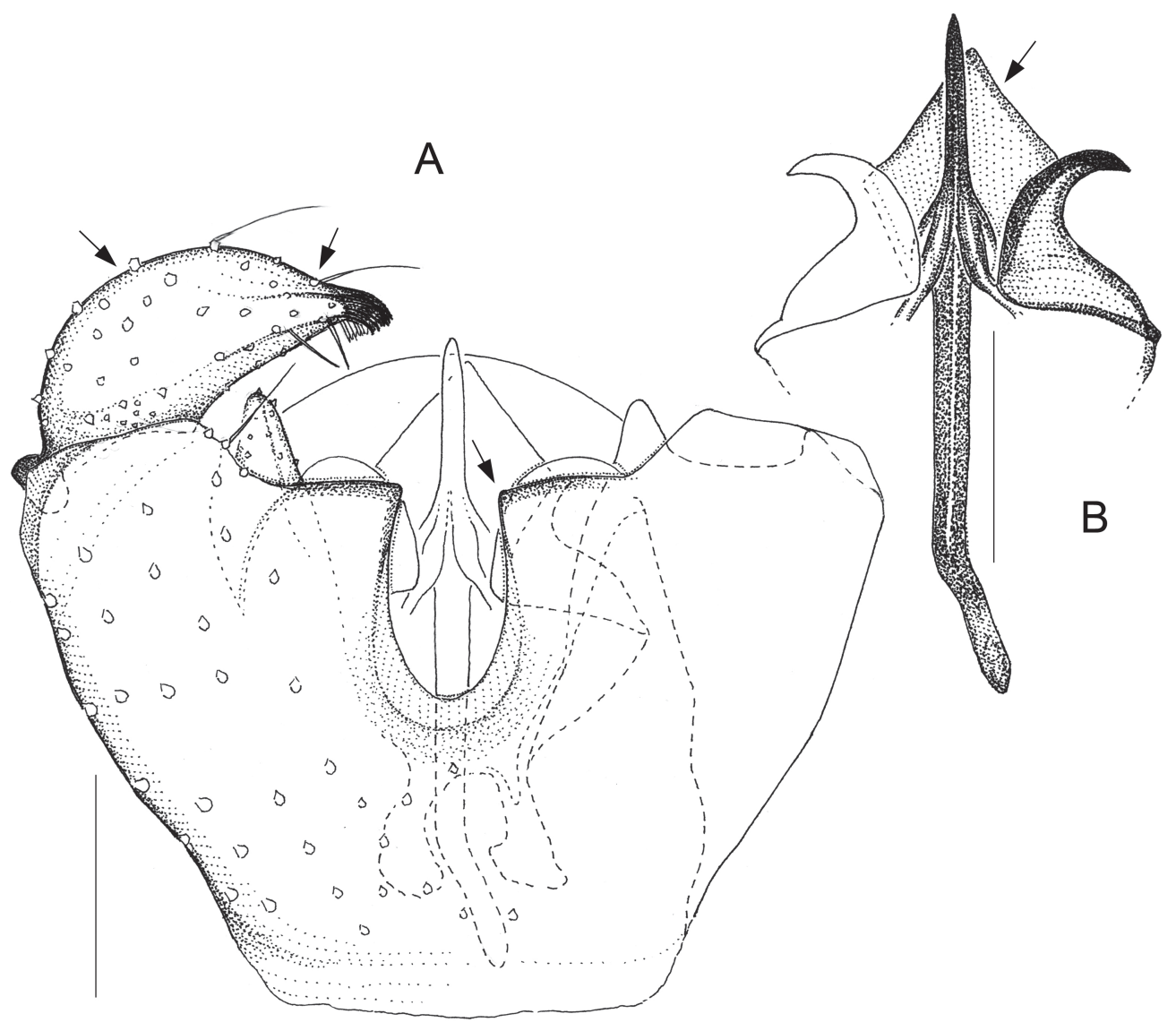

Fig. 6. Antipodosis rakiura gen. et sp. nov., Ô, holotype. A. Genitalia, ventral. B. Parameres and ejaculatory apodeme, ventral. Scale lines: $0.05 \mathrm{~mm}$. 
Antipodosis rotoiti gen. et sp. nov.

urn:1sid:zoobank.org:act:9BA5DA6F-D8D5-4921-B55B-1CC4C739BE76

Fig. 7A-B

\section{Diagnosis}

In this unusual Antipodosis gen. nov., the flattened gonostylus has a broadly rounded apex with wide pectinate tooth ( $\downarrow$, Fig. 7A); the ventral parameral tusks are clearly shorter than the dorsal ( $\downarrow$, Fig. 7B); and the elongate gonocoxites have practically no processes (Fig. 7A).

\section{Etymology}

The species epithet rotoiti is from the Maori language, meaning 'the little lake', with reference to Lake Rotoiti in northern South Island where this new porricondyline was collected.

\section{Type material}

\section{Holotype}

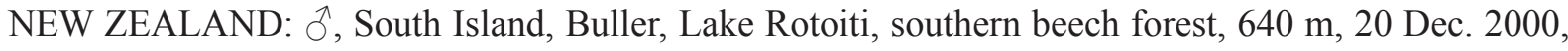
Malaise trap "2", Department of Conservation St Arnaud (NZAC).

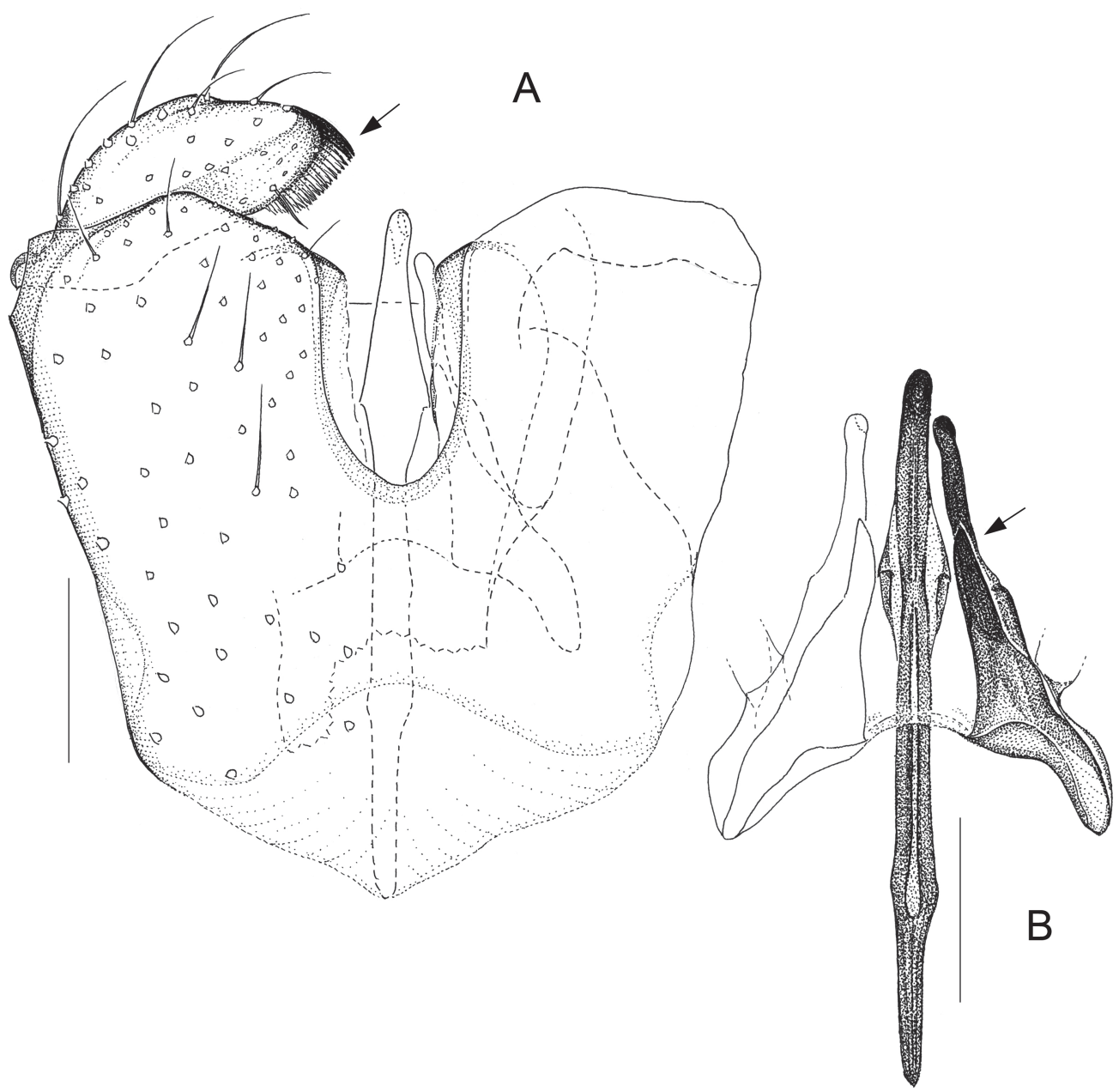

Fig. 7. Antipodosis rotoiti gen. et sp. nov., $\widehat{\jmath}$, holotype. A. Genitalia, ventral. B. Parameres and ejaculatory apodeme, ventral. Scale lines: $0.05 \mathrm{~mm}$. 


\section{Other characters}

BODY LENGTH. $2.1 \mathrm{~mm}$.

HEAD. Eye bridge 4 ommatidia long dorsally. Circumfila on flagellomeres 1-14, often with short posterior extensions. Neck of fourth flagellomere 1.1 times longer than node. Palpus 1.5 times longer than height of head.

WING. Length/width 2.6 .

LeGs. Empodia rudimentary.

Terminalia (Fig. 7A-B). Ninth tergite subtrapezoid. Gonocoxites with asetose, subtriangular portion ventroanteriorly; ventral emargination perfectly U-shaped, with narrow glabrous rim basally; medial bridges with membranous outgrowths that extend into the emargination; apices of apodemes missing, but probably merged to form a plate (Fig. 7A). Ejaculatory apodeme bent ventrally; widened subapically at merging point with accessory gland ducts; flattened basally (Fig. 7B). Ventral parameral tusks almost straight, directed posteriorly, dorsal tusks bent slightly dorsally (Fig. 7B).

Antipodosis rotoroa gen. et sp. nov.

urn:1sid:zoobank.org:act:9C8C71A9-0BCF-4A69-BE42-8ADC45A015C7

Fig. $8 \mathrm{~A}-\mathrm{B}$

\section{Diagnosis}

The gonocoxal processes are more prominent in A. rotoroa gen. et sp. nov. ( $\downarrow$, Fig. 8A) than in any other Antipodosis gen. nov. The gonostylus is slightly curved, tapered towards the apex, and equipped with a long pectinate tooth ( $\downarrow$, Fig. 8A). The apex of the ejaculatory apodeme is two-pointed ( $\downarrow$, Fig. 8B). At the bases of the dorsal parameral tusks are small accessory processes, which are weakly sclerotized and blunt-ended ( $\downarrow$, Fig. 8B).

\section{Differential diagnosis}

See $A$. australis gen. et sp. nov. (Fig. 2) and A. pureora gent. et sp. nov. (Fig. 5) for two species with genitalic structures superficially similar to that found in $A$. rotoroa gen. et sp. nov.

\section{Etymology}

The name rotoroa, which means 'the long lake' in the Maori language, refers to Lake Rotoroa, whose vicinity provides the only habitat yet known of this porricondyline.

\section{Type material}

Holotype

NEW ZEALAND: ${ }^{\lambda}$, South Island, Buller, Lake Rotoroa, mixed podocarp/southern beech forest, 450 m, 15 Jan. 2001, Malaise trap “15”, Department of Conservation St Arnaud (NZAC).

Paratype

NEW ZEALAND: 1 , same data as the holotype (NZAC).

\section{Other characters}

BODY LENGTH. $2.0 \mathrm{~mm}$.

HEAD. Eye bridge 7-8 ommatidia long dorsally. Circumfila on flagellomeres $1-12$. Neck of fourth flagellomere 1.5 times longer than node. Palpus 1.3 times longer than height of head. 
WING. Length/width 2.6.

Legs. Empodia rudimentary.

Terminalia (Fig. 8A-B). Ninth tergite subtrapezoid. Gonocoxites (Fig. 8A): processes subtriangular ( $\downarrow$ ); ventral emargination large, extends beyond midlength of gonocoxites, largely occupied by membranous outgrowths of medial bridges $(\downarrow)$, with glabrous rim basally; apodemes merged into large, subrectangular plate that protrudes far beyond anterior gonocoxal margin $(\downarrow)$. Apex of ejaculatory apodeme bent ventrally (Fig. 8B). Ventral parameral tusks only slightly bent, dorsal tusks directed posteriorly (Fig. 8B).

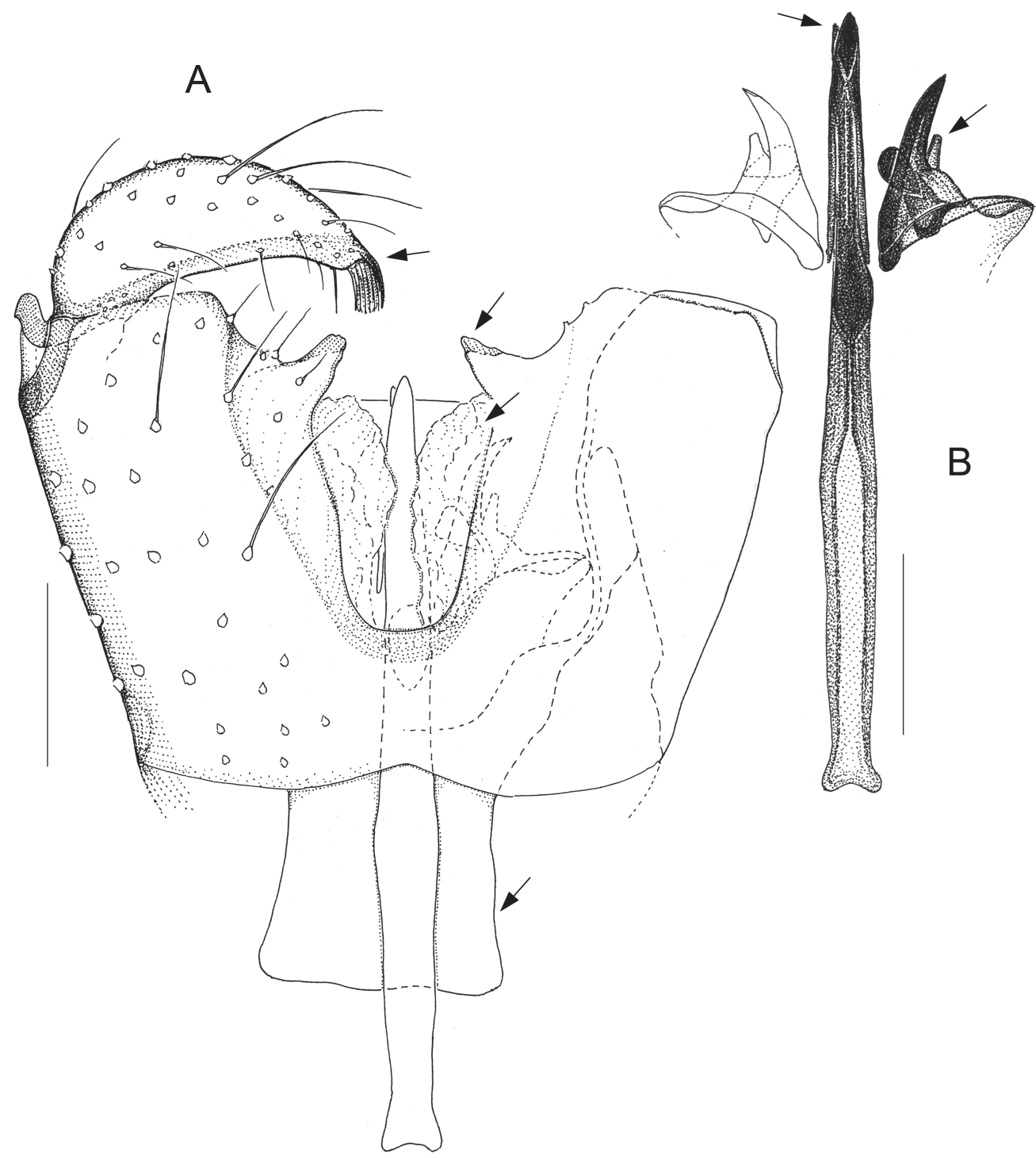

Fig. 8. Antipodosis rotoroa gen. et sp. nov., Ô, holotype. A. Genitalia, ventral. B. Parameres and ejaculatory apodeme, ventral. Scale lines: $0.05 \mathrm{~mm}$. 


\section{Antipodosis waipapa gen. et sp. nov. urn:1sid:zoobank.org:act:53252B20-F0CE-4F56-B7DF-182BBFC599FA}

Fig. 9A-B

\section{Diagnosis}

This is the only species of Antipodosis gen. nov., whose gonostyli have no apical structure, such as a pectinate or solid tooth ( $\downarrow$, Fig. 9A). As another peculiarity, the apical portion of the ejaculatory apodeme is conspicuously enlarged and spoon-shaped ( $\downarrow$, Fig. 9B).

\section{Etymology}

The name waipapa, from the Maori language, refers to Waipapa Reserve in Pureora Forest where the type specimens of this species were collected.

\section{Type material}

\section{Holotype}

NEW ZEALAND: §ิ, North Island, Taupo, Pureora Forest, Waipapa Reserve, shrubland, 570 m, 29 Mar. 1984, Malaise trap, J. Hutcheson (NZAC).

\section{Paratypes}

NEW ZEALAND: 2 $ぇ$, same data as the holotype, but podocarp forest, 17 Nov. 1983 (NZAC).

\section{Other characters (male)}

BODY LENGTH. $2.3 \mathrm{~mm}$.

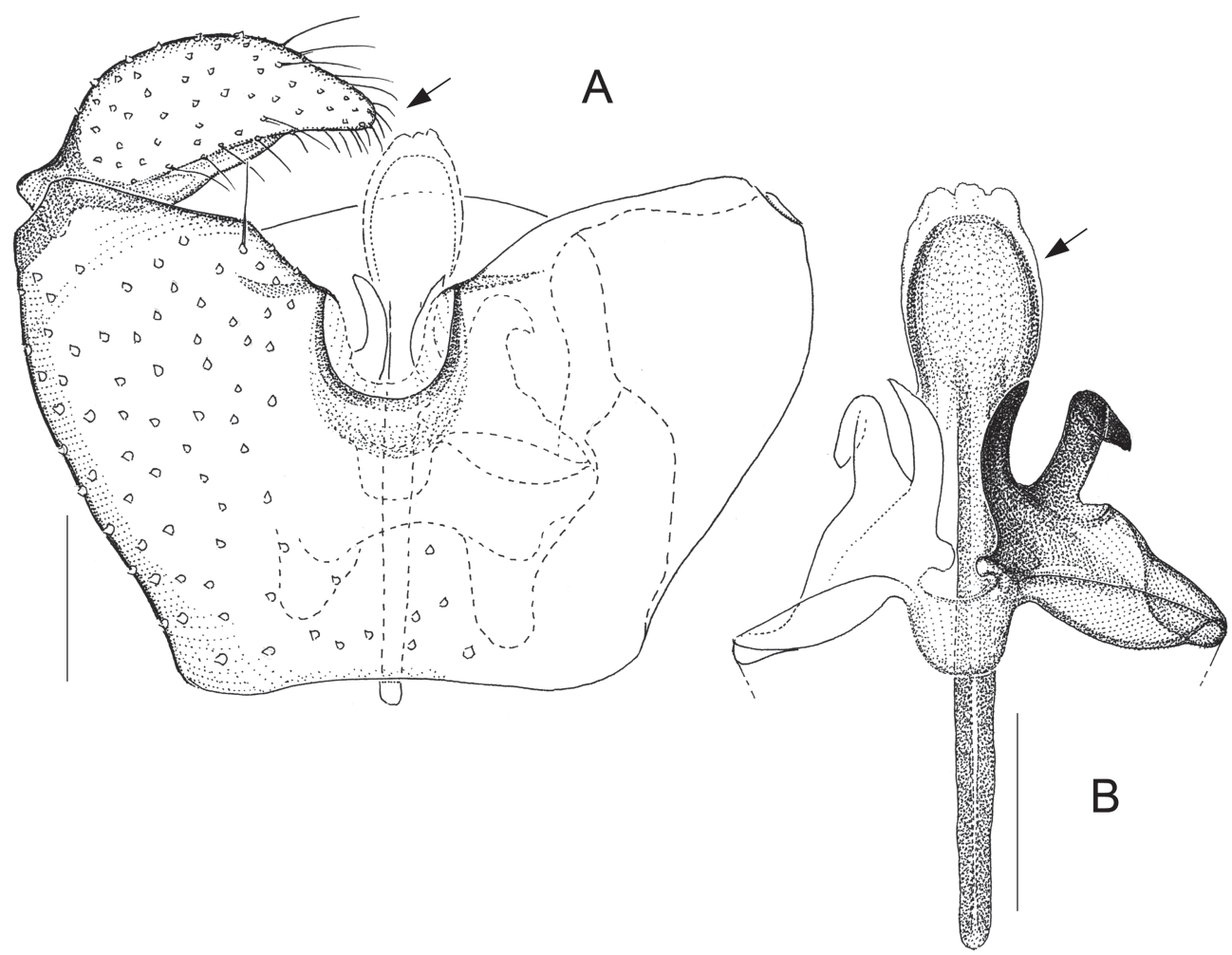

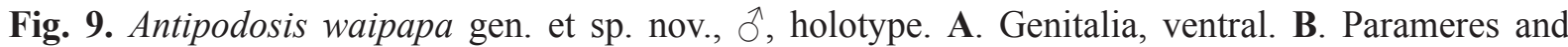
ejaculatory apodeme, ventral. Scale lines: $0.05 \mathrm{~mm}$. 
HEAD. Eye bridge 9-10 ommatidia long dorsally. Scape and pedicel concolorous with flagellum. Neck of fourth flagellomere 1.8 times longer than node. Apices of antennae missing. Palpus 1.6 times longer than height of head.

WING. Length/width 2.5. A short M present at wing margin.

LEGS. Acropods missing, so length of empodia unknown.

Terminalia (Fig. 9A-B). Ninth tergite rounded posteriorly. Gonostylus flattened, rounded apically (Fig. 9A). Gonocoxites (Fig. 9A): true processes missing, medial bridges with membranous outgrowths that extend into the ventral emargination; emargination small, perfectly U-shaped, with glabrous rim basally; apodemes short, bilobed anteriorly. Ventral parameral tusks smaller and less strongly bent than dorsal tusks; parameral apodemes large, connected ventrally by weakly sclerotized bridge (Fig. 9B). Base of ejaculatory apodeme flattened; apical extension covered by membranous cap (Fig. 9B).

Genus Monepidosis Mamaev, 1966

A bibliography including the synonymy of the genus Monepidosis was given in the revision of Porricondylinae by Jaschhof \& Jaschhof (2013). Species of Monepidosis can be distinguished from each other using characters of the male gonocoxites, or more specifically, the processes at the ventroposterior gonocoxal margin, which vary in size, shape and position. There are two kinds of processes: the gonocoxal processes, which are outgrowths of the medial bridges, and the central processes, which are outgrowths of the ventral bridge (Jaschhof \& Jaschhof 2013; this paper, Fig. 10A). Apart from genitalic structures, the morphology of male Monepidosis is extremely uniform. Females and larvae of most Monepidosis species, including the species treated here, are unknown.

Monepidosis heterocera $\mathrm{sp}$. nov. urn:Isid:zoobank.org:act:A0B02B2E-6CB1-488A-8C19-DDB27BC9D43B

Fig. 10A-C

\section{Diagnosis}

A typical Monepidosis (Jaschhof \& Jaschhof 2013: 185), distinguished by the following genitalic characters in combination (Fig. 10A-B). The gonocoxal processes, which arise from a concave, asetose area of varying size ( $\downarrow$, Fig. 10A-B), are nearly as large and prominent $(\downarrow)$ as the central processes. Their apices are typically rounded (Fig. 10A), rarely more pointed (Fig. 10B), and membranous rather than sclerotized. The central processes, separated medially by a V-shaped space, are parallel-sided, unicolored, and end in small, strongly sclerotized hooks ( $\downarrow$, Fig. 10A). The bases of both gonocoxal and central processes are occasionally interconnected by a sclerotized rim, which is very pronounced in the specimen depicted in Fig. 10B $(\downarrow)$.

\section{Remarks on intraspecific variability}

Most of the specimens studied have rounded gonocoxal processes that arise from small depressions (Fig. 10C), so show a combination of the character states figured in A and B. The specimens depicted in $\mathrm{A}$ and $\mathrm{B}$ were initially suspected to belong to different species, until it became obvious that they represent the extreme ends of the range of variation described above. I believe that most of this variation is artificial, i.e. dependent on how a specimen is positioned in the balsam drop.

\section{Differential diagnosis}

Monepidosis heterocera sp. nov. and M. pectinatoides Jaschhof, 2013 resemble each other in having moderately sized, prominent gonocoxal processes and wide, parallel-sided central processes. The two 
species differ in minute details concerning those processes. As characteristics of M. pectinatoides, the gonocoxal processes are sharply pointed and sclerotized apically, and the central processes are bicolored, black laterally, white medially (Jaschhof \& Jaschhof 2013: fig. 89B). Further, the apical portion of the ejaculatory apodeme is more strongly bent ventrally in M. pectinatoides than in any other Monepidosis, including $M$. heterocera sp. nov.

\section{Etymology}

The name heterocera is derived from the Greek words heteros, for 'different', and keras, for 'horn', meaning 'with different horns', which refers to the gonocoxal processes that distinguish this species from its closest relatives.

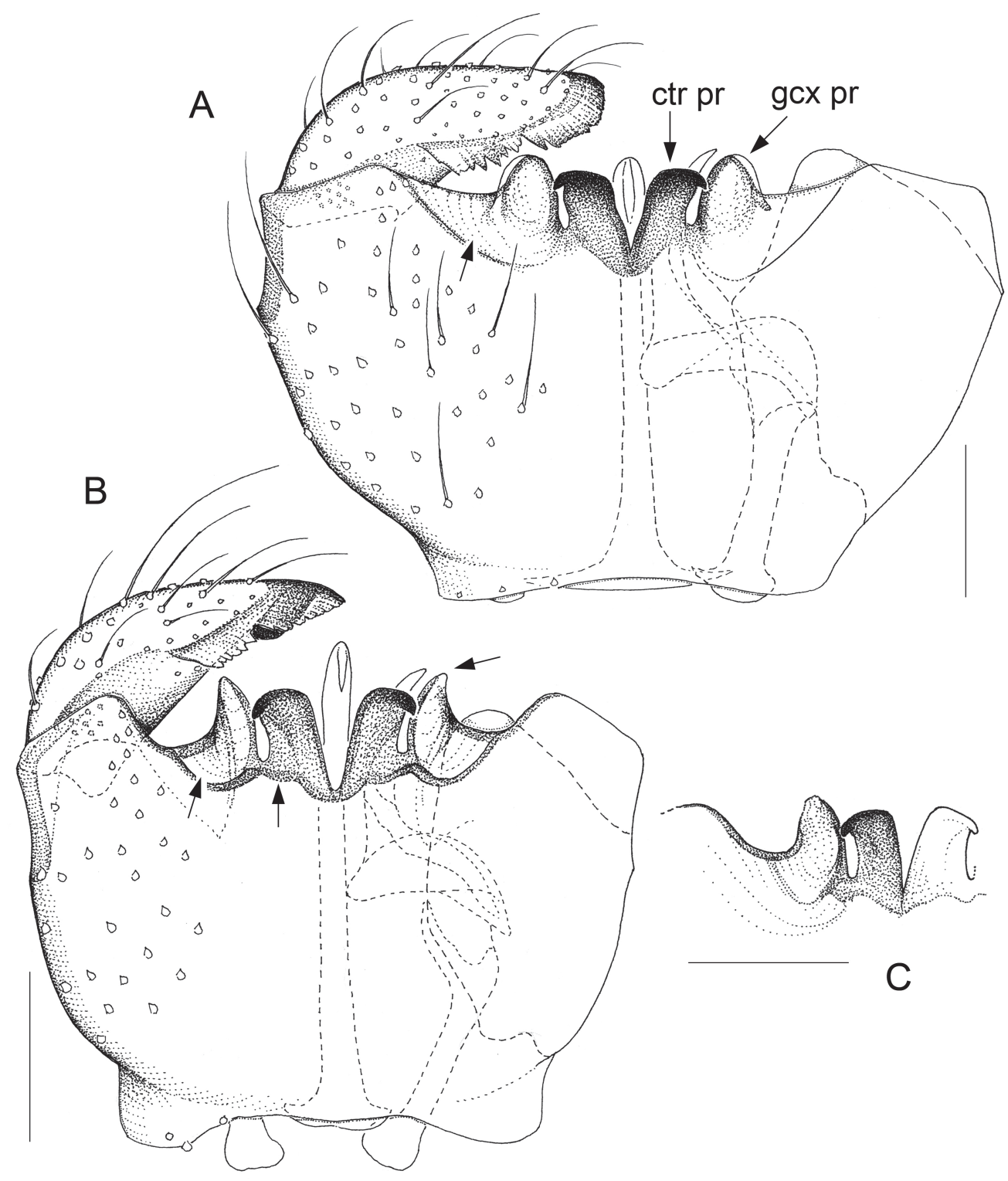

Fig. 10. Monepidosis heterocera sp. nov., đ. A. Genitalia, ventral, holotype. B. Genitalia, ventral (paratype). C. Processes at ventroposterior gonocoxal margin, ventral, paratype. Scale lines: $0.05 \mathrm{~mm}$. 
JASCHHOF M., Taxonomy of Monepidosis and Antipodosis gen. nov.

\section{Type material}

Holotype

SWEDEN: đ̊̄, Öland, Mörbylånga, Skogsby, Station Linné, $56.61^{\circ} \mathrm{N}, 16.49^{\circ} \mathrm{E}$, near compost pile, $1-31$ Jul. 2014, Malaise trap, M. \& C. Jaschhof (NHRS CEC96).

\section{Paratypes}

SWEDEN: 1 ภ, Öland, Gamla Skogsby (Kalkstad), $56.61^{\circ} \mathrm{N}, 16.50^{\circ} \mathrm{E}$, mixed deciduous forest, $1-27$ May 2014, Malaise trap, M. \& C. Jaschhof (NHRS CEC97); $3 \hat{\jmath} \partial^{2}$, same locality, 13 May-8 Jun. 2015, Malaise trap, M. \& C. Jaschhof (NHRS CEC109-110, SDEI CEC111).

Other material examined

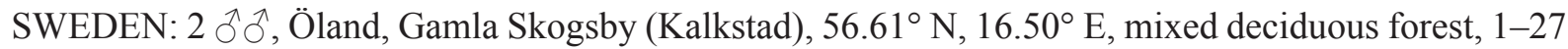
May 2014, Malaise trap, M. \& C. Jaschhof (NHRS ZFMK-TIS2537355-2537356).

GERMANY: $1 \hat{\partial}$, Brandenburg, Schorfheide-Chorin Biosphere Reserve, Barnim, Klein Ziethen, Kernberge near Serwester See, edge of pine forest, 22 Apr. 2009, Malaise trap, leg. SDEI (SDEI A7625); 1 đ, Baden-Württemberg, Malsch, Glaser gravel plant, edge of pine forest, 19 Mar.-21 Apr. 2010, Malaise trap, D. Doczkal (SDEI A7624).

\section{Other characters}

BODY LENGTH. 1.7-1.9 mm.

HeAD. Eye bridge 3-4 ommatidia long dorsally. Circumfila on flagellomeres 1-10. Neck of fourth flagellomere 1.5 times longer than node. Palpus 1.3-1.5 times longer than height of head.

WING. Length/width 2.8-3.0. A remnant M present at wing margin.

Legs. Empodia rudimentary.

Terminalia (Fig. 10A-C). Gonostylus flattened, with plate-like, irregularly serrated spine around apex (Fig. 10A-B). Parameres present as 2 pairs of large, strongly sclerotized, dorsally curved tusks, similar to those found in many other Monepidosis (Jaschhof \& Jaschhof 2013: fig. 88A). Apex of ejaculatory apodeme flattened, bent ventrally; base widened, sclerotized (Fig. 10A-B).

\section{Distribution and phenology}

Sweden (Öland), Germany (Brandenburg, Baden-Württemberg). Adults collected in and near deciduous and coniferous forest from March/April (southwest Germany) to July (southeast Sweden). Possibly a thermophilic species, given that all collection sites are favoured by a warm climate.

\section{Monepidosis scepteroides sp. nov. urn:1sid:zoobank.org:act:60EE7BD9-7842-4026-BA78-050F926D770B}

Figs $1 \mathrm{D}, 11 \mathrm{~A}-\mathrm{C}$

\section{Diagnosis}

Monepidosis scepteroides sp. nov. is the only Monepidosis with only one pair of parameral tusks $(\downarrow$, Fig. 11C). Of the gonocoxites (Fig. 11A), the wide, shallow ventral emargination has a glabrous rim basally $(\downarrow)$; the central processes, which are situated posterior to that rim, form a widely open, unevenly sclerotized V-shape $(\downarrow)$; and gonocoxal processes are missing. 


\section{Differential diagnosis}

Monepidosis scepteroides sp. nov. is similar to M. scepteri Spungis, 2006, especially with respect to the central processes. In M. scepteroides sp. nov., as distinct from M. scepteri, the gonocoxites are wider than long instead of the reverse, and the plate-like gonostylar spine is a single piece rather than consisting of two clearly separated portions (Spungis 2006: fig. 4B). Like all Monepidosis but M. scepteroides sp. nov., M. scepteri has two pairs of parameral tusks (Spungis 2006: fig. 4A).

\section{Etymology}

The name scepteroides, an adjective, refers to the similarity of this species to M. scepteri.

\section{Type material}

\section{Holotype}

SWEDEN: ${ }^{\lambda}$, Mörbylånga, Gamla Skogsby (Kalkstad), $56.61^{\circ} \mathrm{N}, 16.50^{\circ} \mathrm{E}$, mixed deciduous forest, 8 Aug. 2014, aspirator, M. Jaschhof (NHRS CEC94).

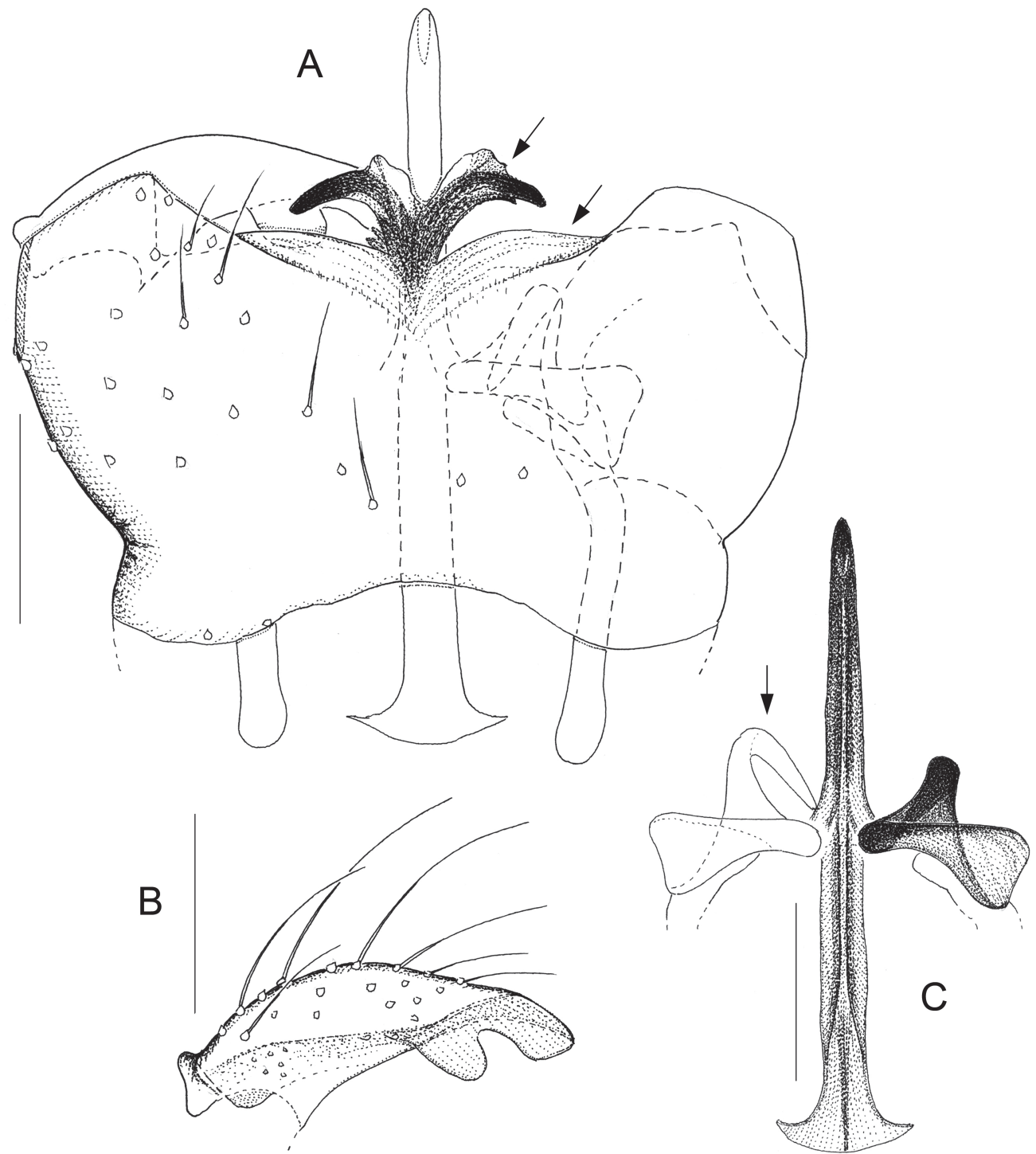

Fig. 11. Monepidosis scepteroides sp. nov., $\widehat{\jmath}$, holotype. A. Genitalia, ventral. B. Gonostylus, ventral (paratype). C. Parameres and ejaculatory apodeme, ventral. Scale lines: $0.05 \mathrm{~mm}$. 


\section{Other characters}

BODY LENGTH. $1.7 \mathrm{~mm}$.

HEAD. Eye bridge 3-4 ommatidia long dorsally. Apices of antennae missing, circumfila on flagellomeres 1-10 at least. Neck of fourth flagellomere 1.9 times longer than node (Fig. 1D). Palpus 1.3 times longer than height of head.

WING. Length/width 3.1 .

Legs. Empodia rudimentary.

Terminalia (Fig. 11A-C). Gonostylus (Fig. 11B) strongly flattened, with long, deeply incised plate-like spine apically and apicoventrally. Apex of ejaculatory apodeme pointed, flattened, bent ventrally; base weakly sclerotized, widened (Fig. 11C). Parameral tusks strongly curved, directed dorsally ( $\downarrow$, Fig. 11C).

\section{Distribution and phenology}

Sweden (Öland). Known from a single specimen collected in deciduous forest in August.

$$
\begin{gathered}
\text { Monepidosis shikokuensis sp. nov. } \\
\text { urn:1sid:zoobank.org:act:7F6FEC96-9091-44F0-849C-3342D230A34F }
\end{gathered}
$$

Figs $1 \mathrm{~B}, 12 \mathrm{~A}-\mathrm{B}$

\section{Diagnosis}

Parameres and ejaculatory apodeme of this highly unusual Monepidosis are merged into a single complex structure (Fig. 12A). The portions of parameral origin, which encircle the ejaculatory apodeme, include vestigial tusks that are curved dorsally $(\downarrow)$. The ejaculatory apodeme is forked into 4 long prongs $(\downarrow)$, of which the laterals have finely serrate apices. The structure of gonostyli and gonocoxites is also exceptional in M. shikokuensis sp. nov. (see section 'Other characters', Fig. 12B).

\section{Etymology}

The name shikokuensis, an adjective, is derived from Shikoku, one of the main islands of Japan, where this species was found.

\section{Type material}

\section{Holotype}

JAPAN: ${ }^{\lambda}$, Shikoku, Kochi, Asakura, $33.55^{\circ} \mathrm{N}, 133.47^{\circ} \mathrm{E}$, secondary growth of mixed evergreen deciduous / coniferous forest, 4-11 Nov. 1998, Malaise trap, M. \& C. Jaschhof (KUEC).

\section{Other characters}

BODY LENGTH. $1.6 \mathrm{~mm}$.

HEAD. Eye bridge 5-6 ommatidia long dorsally. Circumfila on flagellomeres 1-12. Neck of fourth flagellomere 2.1 times longer than node. Palpus 1.3 times longer than height of head.

WING (Fig. 1B). Length/width 3.2.

LEGS. Empodia rudimentary.

Terminalia (Fig. 12A-B). Gonostylus flattened, slightly curved, tapered towards apex, without apical spine ( $\downarrow$, Fig. 12B). Gonocoxites (Fig. 12B): processes missing; ventral emargination unusually large, 
with broad, medially raised microtrichose rim basally $(\downarrow)$; apodemes approach each other. Base of ejaculatory apodeme sclerotized, widened (Fig. 12A).

\section{Distribution and phenology}

Japan (Shikoku). Known from a single specimen collected in evergreen secondary growth in November.

Monepidosis spatulata Spungis, 2006

Monepidosis spatulata Spungis, 2006: 27.

\section{Remark}

Monepidosis spatulata, a species described on the basis of specimens found in Latvia and Lithuania (Spungis 2006), is here reported for the first time from Gotland, Sweden.

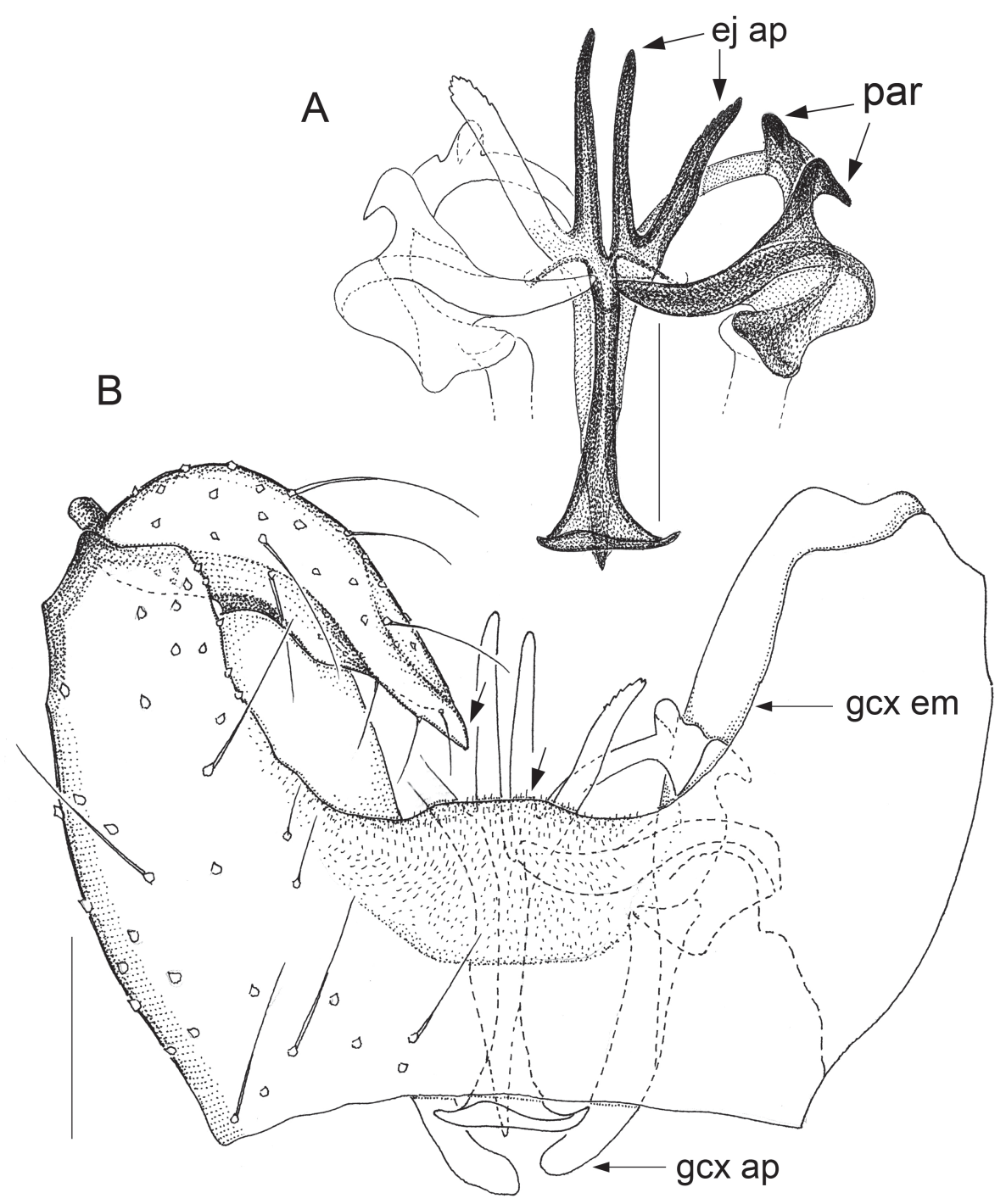

Fig. 12. Monepidosis shikokuensis sp. nov., $\widehat{\jmath}$, holotype. A. Parameres and ejaculatory apodeme, ventral. B. Genitalia, ventral. Scale lines: $0.05 \mathrm{~mm}$. 
JASCHHOF M., Taxonomy of Monepidosis and Antipodosis gen. nov.

\section{Material examined}

SWEDEN: 1 đ (no. CEC98), Gotland, Eksta socken, Stora Karlsö, 8-29 Aug. 2014, Malaise trap, Hymenoptera Inventory Group 2014 (NHRS).

\section{Discussion}

The example of Monepidosis is ideally suited to demonstrate how little we know of the biodiversity of Porricondylinae in Europe, the continent regarded quite rightly as the best-investigated for this and the other subfamilies of fungivorous Cecidomyiidae. Monepidosis is also exemplary for the fact that many Porricondylinae must be regarded as rare in the sense that specimens are seldom found despite great efforts to collect them. This scarcity, which cannot be explained due to the lack of autecological information, makes species inventories fruitful but time-consuming ventures. For example, a nationwide Porricondylinae inventory running in Sweden since 2009 (see Jaschhof \& Jaschhof 2013) found nine different species of Monepidosis to date, of which five were new to science (a tenth species, also new, is known to me from two specimens that are too poorly preserved for description). Some of the morphologically most unusual Monepidosis, such as M. shikokuensis sp. nov., came to be known not from Europe but from Japan, where Porricondylinae have never been surveyed on a systematic basis, meaning that random findings contribute significantly to the overall picture we have of this genus. Antipodosis gen. nov. must be regarded as a similarly random discovery. The 13 specimens I had available to describe Antipodosis gen. nov. and its eight species were accumulated at the time of the 'Lestremiinae of New Zealand' project for curiosity's sake rather than for taxonomy. Another 60 specimens from the same 'bycatch' of New Zealand Porricondylinae belong to 41 different species of 9 genera (Jaschhof, unpublished data), whereas only one porricondyline, Yukawaepidosis aliculata (Yukawa, 1964), was named from the New Zealand region in the past (Gagné 1989; Gagné \& Jaschhof 2014). Finally, the discovery that Antipodosis gen. nov. and Monepidosis are closely related to each other does not necessarily indicate straight affinities between New Zealand and Holarctic Porricondylinae. It remains unknown for the time being whether the Monepidosis group has representatives in southeast Asia, New Guinea, New Caledonia, or Australia, since all these regions are practically unstudied for Porricondylinae.

\section{Acknowledgements}

Research resulting in this paper was funded by Svenska ArtDatabanken (Swedish Species Information Centre) within the framework of Svenska Artprojektet (Swedish Taxonomy Initiative) (dha 2014150 4.3). My wife, Catrin Jaschhof, helped considerably with fieldwork and specimen preparation. Many of the specimens studied here were provided by the fellow entomologists specified in the Material examined sections. Ika Österblad picked out the Cecidomyiidae specimens from insect samples collected on Stora Karlsö. The manuscript was kindly read by Raymond J. Gagné before submission to the journal and by three reviewers unknown to the author after submission; sincere thanks are given to all of them.

\section{References}

Gagné R.J. 1989. 12. Family Cecidomyiidae. In: Evenhuis N.L. (ed.) Catalog of the Diptera of the Australasian and Oceanic Regions: 152-163. Bishop Museum Special Publication 86, Bishop Museum Press and E.J. Brill, Leiden.

Gagné R.J. \&.Jaschhof M. 2014. A Catalog of the Cecidomyiidae (Diptera) of the World. 3rd Edition. Digital version 2. Available from http://www.ars.usda.gov/SP2UserFiles/Place/12454900/Gagne 2014 World_Cecidomyiidae_Catalog_3rd_Edition.pdf [accessed 18 Mar. 2016]

Jaschhof M. 2000. On the Lestremiinae (Diptera: Cecidomyiidae) of Japan. General Introduction and Part 1: Genus Pseudoperomyia Jaschhof \& Hippa, 1999. Esakia 40: 11-35. 
Jaschhof M. \& Jaschhof C. 2003. Wood midges of New Zealand (Cecidomyiidae, Lestremiinae). Part I: Introductory notes and tribes Lestremiini, Strobliellini, Campylomyzini and Pteridomyiini Jaschhof trib. nov. Studia Dipterologica 10: 97-132.

Jaschhof M. \& Jaschhof C. 2013. The Porricondylinae (Diptera: Cecidomyiidae) of Sweden, with notes on extralimital species. Studia Dipterologica Supplement 20: 1-392.

Jaschhof M. \& Jaschhof C. 2015. New species and new distribution records of Lestremiinae, Micromyinae and Porricondylinae (Diptera: Cecidomyiidae) in Sweden. Zootaxa 3973: 159-174. http:// dx.doi.org/10.11646/zootaxa.3973.1.6

Spungis V. 2006. A revision of the gall midges of the genus Monepidosis Mamaev, 1966 (Diptera: Cecidomyiidae, Porricondylinae). Latvijas Entomologs 43: 18-32.

Manuscript received: 2 December 2015

Manuscript accepted: 4 January 2016

Published on: 26 April 2016

Topic editor: Koen Martens

Desk editor: Kristiaan Hoedemakers

Printed versions of all papers are also deposited in the libraries of the institutes that are members of the EJT consortium: Muséum national d'Histoire naturelle, Paris, France; Botanic Garden Meise, Belgium; Royal Museum for Central Africa, Tervuren, Belgium; Natural History Museum, London, United Kingdom; Royal Belgian Institute of Natural Sciences, Brussels, Belgium; Natural History Museum of Denmark, Copenhagen, Denmark. 